\title{
The Decreasing of Homeostatic Model Assessment - Insulin Resistance Levels after Given Coffee Arabica Gayo Leaf Extract (Coffea arabica L.) to Type 2 Diabetes Mellitus Rats
}

Sake Juli Martina ${ }^{1,2 *} \mathbb{D}$, Aznan Lelo ${ }^{1}$, Dharma Lindarto ${ }^{3}$, Ratna Akbari Ganie ${ }^{4}$, Muhammad Ichwan ${ }^{1}$, Hanifah Yusuf ${ }^{5}$, Syafruddin llyas ${ }^{6}$, Iqbal Pahlevi Nasution ${ }^{7}$

${ }^{1}$ Department of Pharmacology and Therapeutics, Faculty of Medicine, Universitas Sumatera Utara, Medan, Indonesia; ${ }^{2}$ Universitas Sumatera Utara Hospital, Medan, Indonesia; ${ }^{3}$ Departmen of Internal Medicine, Faculty of Medicine, Universitas Sumatera Utara, Medan, Indonesia; ${ }^{4}$ Department of Clinical Pathology, Faculty of Medicine, Universitas Sumatera Utara, Medan, Indonesia; ${ }^{5}$ Department of Pharmacology, Faculty of Medicine, Universitas Syiah Kuala, Banda Aceh, Indonesia; ${ }^{6}$ Department of Biology, Faculty of Mathematics and Natural Sciences, Universitas Sumatera Utara, Medan, Indonesia; ${ }^{7}$ Department of Pediatric Surgery, Faculty of Medicine, Universitas Sumatera Utara, Medan, Indonesia

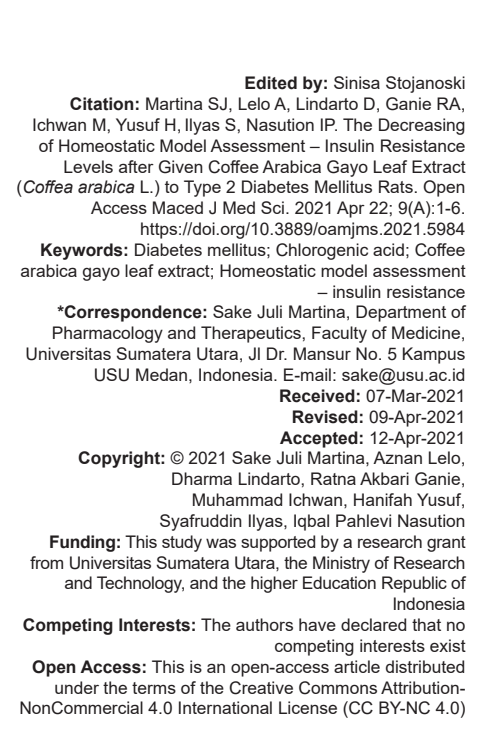

\section{Abstract}

BACKGROUND: Diabetes mellitus (DM) continues to increase with currently more than 463 million people in the world live with DM. One of the causes of Type 2 DM (T2DM) is insulin resistance. Determining laboratory-based tests for early identification of T2DM is important. One of the tests developed was the detection of homeostatic model assessment - insulin resistance (HOMA-IR) levels.

AIM: Using chlorogenic acid found in coffee leaves as antidiabetic agent for alternative treatments in DM, this research is conducted to understand the effect of Coffee Arabica Gayo Leaf Extract (Coffea arabica L.) in decreasing HOMA-IR levels in T2DM rats.

MATERIALS AND METHODS: Thirty-five male Wistar rats (Rattus norvegicus) had T2DM induced using a combination of feeding a high-fat diet for 5 weeks followed by multiple intraperitoneal injections of low-dose streptozotocin (30 mg/kgBW), divided into 7 groups (2 groups that did not receive treatment [K1 and $\mathrm{K} 3$ ] and 5 groups that received treatment $[K 2, K 4, K 5, K 6, K 7])$. The extract was administered with dosage 150, 200, and $250 \mathrm{mg} / \mathrm{kgBW} /$ day through a nasogastric tube for 30 days. Then, the HOMA-IR value will be obtained by multiplying fasting plasma insulin by fasting plasma glucose, then divide by a constant of 22.5 .

RESULTS: The study showed a significant difference before and after treatment, $p$ value was $<0.05$, which a decrease HOMA-IR levels $(p=0.002$ ) after given Coffee Arabica Gayo Leaf Extract at 200 and $250 \mathrm{mg} / \mathrm{kgBW} / \mathrm{day}$ to Wistar rats for 30 days. The decrease HOMA-IR levels are greater than The T2DM group that received metformin and group without treatment.

CONCLUSION: Coffee Arabica Gayo Leaf Extract can significantly decrease HOMA-IR levels at a dose of 200 and $250 \mathrm{mg} / \mathrm{kgBW}$. The decrease of HOMA-IR levels is greater than The T2DM group that received metformin and group without treatment.

\section{Introduction}

Studies have shown a tendency to increase the incidence and prevalence of Type 2 diabetes mellitus (T2DM) in various parts of the world. Type 2 diabetes as the most common type of diabetes currently accounted for around $90 \%$ of all diabetes cases. International Diabetes Federation (IDF) in 2019 states that currently there are more than 463 million people in the world live with DM. For example, it is predicted that the prevalence of DM throughout the world will increase to 578 million in 2045. Diabetes continues to increase steadily in the world, especially in developed countries. It is also expected to continue to increase in the next 20 years with more than $70 \%$ of patients will appear in developing countries with the majority aged 45-64 years [1], [2].

T2DM is generally characterized by insulin resistance. There are several studies on the basic mechanisms of insulin resistance at the molecular level, including abnormal insulin production, mutations of insulin receptors and their substrates, and insulin antagonists. Some of the mechanisms that cause insulin resistance involve transmembrane receptors on the cell surface, signal transduction defects, glucose transportation abnormalities, and others [3].

Insulin resistance is a strong predictor of measuring the progression of T2DM and targeted therapy for hyperglycemia. Insulin resistance can be enforced through homeostatic model assessment 
- insulin resistance (HOMA-IR), a method for assessing $\beta$ cell function and insulin resistance from basal glucose (fasting) and insulin concentration. The results were obtained by multiplying fasting plasma insulin (FPI) by fasting plasma glucose (FPG), then dividing by a constant of 22.5. HOMA-IR assesses $\beta$-cell function and thus informs the physiological changes that occur before the onset of T2DM (the precursor of T2DM), which makes this test a potential tool for identifying people at high risk of developing T2DM [4].

Since long ago, plants have been used for the treatment of T2DM around the world. Large varieties of these plants have been evaluated and have been confirmed to have hypoglycemic effects in animal models such as alkaloids, terpenoids, flavonoids, polysaccharides, and saponins [5]. Coffee leaves are one of many types of plants which is known to have been antidiabetic effect, but it is efficacy has not been researched enough. Chlorogenic acid is a new insulin sensitizer that potentiates the action of insulin similar to metformin. Chlorogenic acid has been described as a potential antidiabetic agent. Coffee including the leaves is a complex mixture of chemicals that provides a large amount of chlorogenic acid. It was reported that daily consumption of chlorogenic acid significantly reduced the risk of T2DM by $30 \%$. Other clinical trials have also shown that chlorogenic acid can reduce blood glucose in T2DM patients [6], [7], [8]. Therefore, this study is conducted to know the effect of Coffee Arabica Gayo Leaf Extract (Coffea arabica L.) in decreasing HOMA-IR levels.

\section{Research Methodology}

\section{Research type and location}

This research was conducted with experimental type research. The research was conducted at the Pharmacology and Therapeutic Laboratory of the Faculty of Medicine, Universitas Sumatera Utara, Indonesia.

\section{Materials}

In this study, the ingredients used to reduce blood glucose level (BGL) were:

1. Metformin

2. Coffee Arabica Gayo Leaf Extract (C. arabica L.).

\section{Animal}

This study used male white rats, Wistar strain aged 8 weeks with a bodyweight of $180-200 \mathrm{~g}$, the mice used were healthy and had never been tried in other studies. Using Federer's formula (1963), all experimental animals used were around 35 rats [9].

\section{Induction DM}

Rats were acclimatized for 7 days, given food and drink ad libitum. One mouse was placed in a cage in a room with a temperature of $22-25^{\circ} \mathrm{C}$ with a lightdark cycle of $12 / 12 \mathrm{~h}$. The mice were given a standard diet consisting of $12 \%$ fat, $60 \%$ carbohydrates, and $28 \%$ protein for 2 days, then were given a high-fat diet (HFD) consisting of $41 \%$ fat, $41 \%$ carbohydrates, and $18 \%$ protein for 5 weeks. After 5 weeks, the rats were fasted for 1 night, then they were injected with a low dose of streptozotocin $(30 \mathrm{mg} / \mathrm{kgBW}$ in 0.1 citrate buffer, $\mathrm{pH} 4.5)$ = intraperitoneally. Injection of streptozotocin dose of $30 \mathrm{mg} / \mathrm{kgBW}$ in 0.1 citrate buffer, $\mathrm{pH} 4.5$ was repeated for the following week. After 1 week of the second administration of streptozotocin, BGLs when checked with a glucometer and if more than $200 \mathrm{mg} / \mathrm{dl}$, then fasting BGLs and fasting insulin levels are checked to ensure insulin resistance and T2DM have occurred in experimental animals. When measuring BGLs above $200 \mathrm{mg} / \mathrm{dl}$, rats are said to have T2DM.

\section{Treatment}

Wistar rats that had been induced with HFD/streptozotocin (STZ) were then found to have BGLs indicating a value that indicated T2DM on the measurement of blood sugar. Wistar rats were divided into two large groups, namely the normal group that was not made the T2DM model $(n=10)$ and the T2DM model group $(n=25)$. All experimental animals in the T2DM model group were induced with a low dose of STZ $30 \mathrm{mg} / \mathrm{kgBW}$ (1-week interval) after being given a HFD for 5 weeks to make it a T2DM model. Wistar rats that had become T2DM were divided randomly into 5 groups, namely the T2DM group without treatment $(n=5)$, the T2DM group with metformin $(n=5)$, the T2DM group with the administration of Coffee Arabica Gayo Leaf Extract (C. arabica L.) at a dose of $150 \mathrm{mg} / \mathrm{kgBW} /$ day $(n=5)$, the T2DM group was given the Coffee Arabica Gayo Leaf Extract (C. arabica L.) at a dose of $200 \mathrm{mg} / \mathrm{kgBW} /$ day $(\mathrm{n}=5)$, and the T2DM group was given Coffee Arabica Gayo Leaf Extract (C. arabica L.) at a dose of $250 \mathrm{mg} / \mathrm{kgBW} /$ day $(\mathrm{n}=5)$. Likewise, the group of mice that were not made the T2DM model was divided into 2 groups randomly, namely the normal control group without treatment $(n=5)$ and the normal control group with the administration of Coffee Arabica Gayo Leaf Extract (C. arabica L.) at a dose of $250 \mathrm{mg} / \mathrm{kgBW} /$ day $(\mathrm{n}=5)$. Hence, the total number of groups (t) in this study was 7 groups consisting of 2 Normal groups and 5 T2DM groups. Of these 7 groups, there were 2 groups that did not receive treatment (K1 and $\mathrm{K} 3$ ) and 5 groups that received treatment (K2, $\mathrm{K} 4, \mathrm{~K} 5, \mathrm{~K} 6, \mathrm{~K} 7$ ). The extract was administered at a 
dose of $150 \mathrm{mg} / \mathrm{kgBW} /$ day, $200 \mathrm{mg} / \mathrm{kgBW} /$ day, and $250 \mathrm{mg} / \mathrm{kgBW} /$ day of oral rats through a nasogastric tube for 30 days.

\section{Blood sugar check procedure}

The measured rat blood was taken from a lateral vein in the rat's tail, the tip of the tail was sheared, and then the rat's tail was pressed until it drained a drop of blood. Then, put a drop of blood into the AutoCheck.

\section{HOMA-IR calculation}

HOMA-IR level is obtained by multiplying FPI by FPG, then dividing it by a constant of 22.5 , e.g.:

$$
\text { HOMA-IR = }(F P I \times F P G) / 22.5
$$

For the cutoff value of HOMA-IR in humans, there are some differences between the previous, so we used a study recommended by $\mathrm{Qu}$ et al. where HOMA-IR below 2.6 is the normal range, 2.6-3.8 as borderline high without labeling this individual as having insulin resistance, and 3.8 as high and clearly correlates with insulin resistance with a specificity of $81.8 \%$ and a sensitivity of $64.1 \%$ [10].

\section{Statistical analysis}

To assess whether the sample is normally distributed or not, the Shapiro-Wilk test is carried out because the sample is $<50$. Data are presented in the form of mean, standard deviation because it is normally distributed. To assess the comparison of parameters between the control group and the treatment group, the one-way ANOVA test analysis was used. Data were processed and analyzed using SPSS with a significance limit of $p<0.05$

\section{Results and Discussions}

Based on the research that has been done, it shows that from 35 mice, there were changes in fasting BGL from before the intervention and after the intervention of each group. The reading results are then processed and averaged from each intervention group which produces the following data:

Table 1 shows that the mean fasting BGLs of male Wistar rats after being induced into the T2DM model in the T2DM group were higher than the non-induced T2DM model $(79.40 \pm 1.63 \mathrm{mg} / \mathrm{dl}$ [K1], $81.20 \pm 1.90 \mathrm{mg} / \mathrm{dl}$ [K2], $291.00 \pm 5.95 \mathrm{mg} / \mathrm{dl}$ [K3], $290.60 \pm 4.08 \mathrm{mg} / \mathrm{dl}$ [K4], $293.60 \pm 3.07 \mathrm{mg} / \mathrm{dl}$ [K5], $292.20 \pm 2.74 \mathrm{mg} / \mathrm{dl}$ [K6], and $281.80 \pm 1.82 \mathrm{mg} / \mathrm{dl}[\mathrm{K} 7])$ with $\mathrm{p}=0.025$. The order of the mean fasting BGLs of male Wistar rats after T2DM from the highest to the lowest was K5 $(293.60 \pm 3.07 \mathrm{mg} / \mathrm{dl})>$ $\mathrm{K} 6(292.20 \pm 2.74 \mathrm{mg} / \mathrm{dl})>\mathrm{K} 4(290.60 \pm 4.08 \mathrm{mg} / \mathrm{dl})>\mathrm{K} 7$ $(281.80 \pm 1.82 \mathrm{mg} / \mathrm{dl})>\mathrm{K} 3(291.00 \pm 5.95 \mathrm{mg} / \mathrm{dl})>\mathrm{K} 2$ $(81.20 \pm 1.90 \mathrm{mg} / \mathrm{dl})>\mathrm{K} 1(79.40 \pm 1.63 \mathrm{mg} / \mathrm{dl})$.

Meanwhile in Table 2, it shows that the mean fasting BGLs of male Wistar rats in the T2DM model after intervention in the T2DM group who did not get the intervention were significantly higher than the average fasting BGLs in the group that received the intervention $(79.20 \pm 1.46 \mathrm{mg} / \mathrm{dl}$ [K1], $81.20 \pm 2.81 \mathrm{mg} / \mathrm{dl}$ [K2], 289.0 $\pm 7.48 \mathrm{mg} / \mathrm{dl}$ [K3], $82.40 \pm 9.42 \mathrm{mg} / \mathrm{dl}$ [K4], $109.60 \pm$ $4.00 \mathrm{mg} / \mathrm{dl}$ [K5], $87.0 \pm 5.726 \mathrm{mg} / \mathrm{dl}[\mathrm{K} 6]$, and $64.60 \pm$ $2.37 \mathrm{mg} / \mathrm{dl}[\mathrm{K} 7]$ ) with $\mathrm{p}=0.003$. The order of the mean fasting BGLs of male Wistar rats after T2DM from the highest to the lowest was K3 $(289.00 \pm 7.48 \mathrm{mg} / \mathrm{dl})>$ $\mathrm{K} 5(109.60 \pm 4.00 \mathrm{mg} / \mathrm{dl})>\mathrm{K} 6(87.0 \pm 5.726 \mathrm{mg} / \mathrm{dl})>$ $\mathrm{K} 4(82.40 \pm 9.42 \mathrm{mg} / \mathrm{dl})>\mathrm{K} 2(81.20 \pm 2.81 \mathrm{mg} / \mathrm{dl})>\mathrm{K} 1$ $(79.20 \pm 1.46 \mathrm{mg} / \mathrm{dl})>\mathrm{K} 7(64.60 \pm 2.37 \mathrm{mg} / \mathrm{dl})$.

From Figure 1, we can see that the decrease in $B G L$ in the T2DM group who received the intervention of Coffee Arabica Gayo Leaf Extract (C. arabica L.) at a dose of $250 \mathrm{mg} / \mathrm{kgBW}$ had the highest reduction in BGL even compared to the group that received metformin (K7 $>\mathrm{K} 4$ ). In the picture, it is also seen that the higher the dose of Coffee Arabica Gayo Leaf Extract (C. arabica $L$.), the higher the decrease in BGL that occurs (delta $\mathrm{K} 7>\mathrm{K} 6>\mathrm{K} 5$ ). In addition, it can be seen in figure that the decrease in BGL in the group receiving Coffee Arabica Gayo Leaf Extract (C. arabica L.) at a dose of $200 \mathrm{mg} / \mathrm{kgBW}$ was almost the same as the group receiving metformin (delta $\mathrm{K} 6=\mathrm{K} 4$ ).

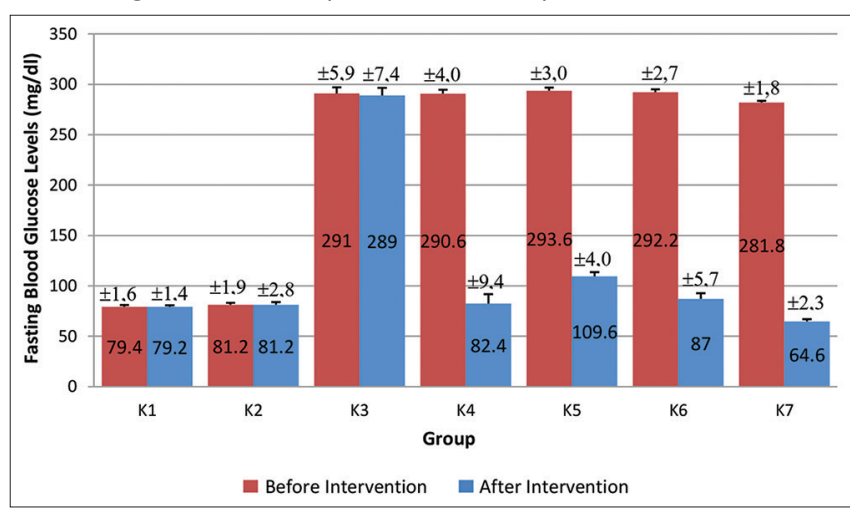

Figure 1: Fasting blood glucose levels in Type 2 diabetes mellitus. Model Wistar rats before and after intervention

Table 3 shows that the mean fasting insulin levels of male Wistar rats in the treatment group was

Table 1: Data of fasting blood glucose levels in T2DM model Wistar rats before intervention

\begin{tabular}{|c|c|c|c|c|c|c|c|c|}
\hline Group & $\mathrm{K} 1(\mathrm{n}=5)$ & K2 $(n=5)$ & K3 $(n=5)$ & $\mathrm{K} 4(\mathrm{n}=5)$ & $\mathrm{K} 5(\mathrm{n}=5)$ & K6 (n=5) & K7 (n=5) & $\mathrm{p}$ \\
\hline Fasting blood glucose levels (mg/dl) & $79.40 \pm 1.63$ & $81.20 \pm 1.90$ & $291.00 \pm 5.96$ & $290.60 \pm 4.08$ & $293.60 \pm 3.07$ & $292.20 \pm 2.74$ & $281.80 \pm 1.82$ & $0.025^{*}$ \\
\hline
\end{tabular}


Table 2: Data of fasting blood glucose levels in T2DM model Wistar rats after intervention

\begin{tabular}{|c|c|c|c|c|c|c|c|c|}
\hline Group & $\mathrm{K} 1(\mathrm{n}=5)$ & $\mathrm{K} 2(\mathrm{n}=5)$ & $\mathrm{K} 3(\mathrm{n}=5)$ & $\mathrm{K} 4(\mathrm{n}=5)$ & K5 $(n=5)$ & $\mathrm{K} 6(\mathrm{n}=5)$ & K7 $(n=5)$ & $\mathrm{p}$ \\
\hline Fasting BGL (mg/dl) & $79.20 \pm 1.46$ & $81.20 \pm 2.81$ & $289.00 \pm 7.48$ & $82.40 \pm 9.42$ & $109.60 \pm 4.00$ & $87.00 \pm 5.72$ & $64.60 \pm 2.37$ & $0.003^{*}$ \\
\hline
\end{tabular}

Table 3: Differences in mean fasting blood glucose levels, fasting insulin levels, and HOMA-IR levels in Wistar rats model T2DM in the control group and the treatment group with coffee arabica Gayo leaf extract

\begin{tabular}{|c|c|c|c|c|c|c|c|c|}
\hline Group & K1 $(n=5)$ & K2 $(n=5)$ & K3 $(n=5)$ & K4 $(n=5)$ & $\mathrm{K} 5(\mathrm{n}=5)$ & $\mathrm{K} 6(\mathrm{n}=5)$ & K7 (n=5) & $\mathrm{p}$ \\
\hline Fasting insulin levels $(\mu \mathrm{IU} / \mathrm{ml})$ & $5.98 \pm 1.75$ & $5.40 \pm 0.40$ & $5.55 \pm 0.39$ & $6.08 \pm 0.10$ & $5.50 \pm 0.13$ & $5.43 \pm 0.34$ & $6.24 \pm 0.14$ & 0.056 \\
\hline HOMA-IR & $21.07 \pm 0.70$ & $19.59 \pm 1.92$ & $71.34 \pm 5.07$ & $22.14 \pm 2.21$ & $26.85 \pm 1.36$ & $21.05 \pm 2.04$ & $17.94 \pm 0.86$ & $0.002^{*}$ \\
\hline
\end{tabular}

$\mathrm{K} 4=\mathrm{T} 2 \mathrm{DM}+$ metformin group, K5=T2DM group + extract dose of $150 \mathrm{mg} / \mathrm{kgBW} / \mathrm{day}, \mathrm{K} 6=\mathrm{T} 2 \mathrm{DM}$ group + extract dose of $200 \mathrm{mg} / \mathrm{kgBW} / \mathrm{day}, \mathrm{K} 7=\mathrm{T} 2 \mathrm{DM}$ group + extract dose of $250 \mathrm{mg} / \mathrm{kgBW} / \mathrm{day}$. T2DM: Type 2 diabetes mellitus.

higher than the untreated group $[5.98 \pm 1.75 \mu \mathrm{lU} / \mathrm{ml}$ (K1), $5.40 \pm 0.40 \mu \mathrm{lU} / \mathrm{ml}(\mathrm{K} 2), 5.55 \pm 0.39 \mu \mathrm{lU} / \mathrm{ml}(\mathrm{K} 3)$, $6.08 \pm 0.10 \mu \mathrm{lU} / \mathrm{ml}(\mathrm{K} 4), 5.50 \pm 0.13 \mu \mathrm{lU} / \mathrm{ml}(\mathrm{K} 5)$, $5.43 \pm 0.34 \mu \mathrm{lU} / \mathrm{ml}(\mathrm{K} 6)$, and $6.24 \pm 0.14 \mu \mathrm{lU} / \mathrm{ml}(\mathrm{K} 7)]$ with $p=0.056$ which means $p \geq 0.05$. Therefore, the difference in the mean value of fasting insulin levels in groups $\mathrm{K} 1-\mathrm{K} 7$ was not statistically significant. The order of the mean fasting insulin levels of male Wistar rats after giving the Coffee Arabica Gayo Leaf Extract (C. arabica L.) from the largest to the smallest was $\mathrm{K} 7(6.24 \pm 0.14 \mu \mathrm{lU} / \mathrm{ml})>\mathrm{K} 4(6.08 \pm 0.10 \mu \mathrm{lU} / \mathrm{ml})>$ $\mathrm{K} 1(5.98 \pm 1.75 \mu \mathrm{lU} / \mathrm{ml})>\mathrm{K} 3(5.55 \pm 0.39 \mu \mathrm{lU} / \mathrm{ml})>$ $\mathrm{K} 5(5.50 \pm 0.13 \mu \mathrm{lU} / \mathrm{ml})>\mathrm{K} 6(5.43 \pm 0.34 \mu \mathrm{lU} / \mathrm{ml})>$ $\mathrm{K} 2(5.40 \pm 0.40 \mu \mathrm{lU} / \mathrm{ml})$. Based on this sequence, we see that only the T2DM group received Coffee Arabica Gayo Leaf Extract at a dose of $250 \mathrm{mg} / \mathrm{kgbb}$ (K7) and the T2DM group received metformin (K4) which had more than normal fasting insulin levels (K1).

The mean of HOMA-IR male Wistar rats in the T2DM group was higher than the normal group (not T2DM) (21.07 \pm 0.70 [K1], $19.59 \pm 1.92$ [K2], $71.34 \pm$ 5.07 [K3], $22.14 \pm 2.21$ [K4], $26.85 \pm 1.36$ [K5], $21.05 \pm$ 2.04 [K6], and 17. $94 \pm 0.86$ [K7]) with $p=0.002$. The mean order of HOMA-IR male Wistar rats after giving the Coffee Arabica Gayo Leaf Extract (C. arabica L.) from the smallest to the largest was K7 (17.94 \pm 0.86$)$ $<\mathrm{K} 2(19.59 \pm 1.92)<\mathrm{K} 6(21.05 \pm 2.04)<\mathrm{K} 1(21.07$ $\pm 0.70)<\mathrm{K} 4(22.14 \pm 2.21)<\mathrm{K} 5(26.85 \pm 1.36)<\mathrm{K} 3$ $(71.34 \pm 5.07)$. It can be seen that there is a decrease in HOMA-IR levels after administering the Coffee Arabica Gayo Leaf Extract (C. arabica L.) to male Wistar rats model T2DM model and it is statistically significant.

In Table 3, it can be seen that after the intervention, there was a significant decrease in the mean fasting blood sugar level and the HOMA-IR value. However, there was no significant difference in fasting insulin levels. Table 4 shows that the Coffee Arabica Gayo Leaf Extract (C. arabica L.) at a dose of 250 $\mathrm{mg} / \mathrm{kgbb}(\mathrm{K} 7)$ has the lowest HOMA-IR value compared to the other T2DM group even lower than the normal group that is not T2DM (K1). In addition, in the figure, we see that the decrease in the HOMA-IR value in the Coffee Arabica Gayo Leaf Extract (C. arabica L.) group is directly proportional with the dose given. It can be seen that the decrease in the value of HOMA-IR in the extract group dose $250 \mathrm{mg} / \mathrm{kBB}$ (K7) >dose $200 \mathrm{mg} / \mathrm{kBB}(\mathrm{K} 6)$ >dose $150 \mathrm{mg} / \mathrm{kgbb}$ (K5). From the picture, it can also be seen that the HOMA-IR value of the Gayo Arabica Coffee Leaf Extract group at a dose of $200 \mathrm{mg} / \mathrm{kgbb}$ (K6) is almost the same as the T2DM group that received metformin (K4) and almost the same as the normal group (K1), namely $\mathrm{K} 6 \geq \mathrm{K} 4 \geq \mathrm{K} 1$. In addition, from Table 4, we see that the HOMA-IR value in the group given ethanol extract at a dose of $250 \mathrm{mg} / \mathrm{kgbb}$ had a low HOMA-IR value both in the T2DM group (K7) and in the non-T2DM group (K2). In the figure, we also see that the HOMA-IR value which is lower than the value in the normal group (K1) sequentially from the smallest to the largest is the Coffee Arabica Gayo Leaf Extract (C. arabica L.) at a dose $250 \mathrm{mg} / \mathrm{kgbb}$ (K7) <normal group who got the ethanol extract of Gayo Arabica Coffee Leaves at a dose of 250 mg/kgbb (K2) <the Coffee Arabica Gayo Leaf Extract (C. arabica L.) at a dose of $200 \mathrm{mg} / \mathrm{kgbb}$ (K6). The rest had a HOMA-IR value greater than the value in the normal group (K1).

Table 4: Results of post hoc Bonferroni homeostatic model assessment - insulin resistance levels analysis after intervention

\begin{tabular}{lllll}
\hline Group & Mean difference & \multicolumn{2}{l}{ Cl 95\% } & $\mathrm{p}$ \\
\cline { 3 - 4 } & & Minimum & Maximum & \\
\hline K3 versus K4 & $49.2^{*}$ & 37.6 & 60.7 & 0.000 \\
K3 versus K5 & $44.4^{*}$ & 32.9 & 56.0 & 0.000 \\
K3 versus K6 & $50.2^{*}$ & 38.7 & 61.8 & 0.000 \\
K3 versus K7 & $53.3^{*}$ & 41.8 & 64.9 & 0.000 \\
K4 versus K5 & -4.7 & -16.2 & 6.8 & 1.000 \\
K4 versus K6 & 1.0 & -10.4 & 12.6 & 1.000 \\
K4 versus K7 & 4.1 & -7.3 & 15.7 & 1.000 \\
K5 versus K6 & 5.7 & -5.7 & 17.3 & 1.000 \\
K5 versus K7 & 8.9 & -2.6 & 20.4 & 0.322 \\
K6 versus K7 & 3.1 & -8.4 & 14.6 & 1.000 \\
\hline
\end{tabular}

Data shown in mean $\pm \mathrm{SD}$ form (post hoc Bonferroni test). ${ }^{*} \mathrm{p}<0.05$ was statistically significant. K1=Norma group without treatment, $\mathrm{K} 2=\mathrm{Normal}$ group + extract dose of $250 \mathrm{mg} / \mathrm{kgBW} / \mathrm{day}, \mathrm{K} 3=\mathrm{T} 2 \mathrm{DM}$ group withou treatment, $K 4=T 2 D M+$ etform treatment, K4=T2DM group + extract dose of $200 \mathrm{mg} / \mathrm{kgBW} /$ day, $\mathrm{K} 7=\mathrm{T} 2 \mathrm{DM}$ group + extract dose of $250 \mathrm{mg} / \mathrm{kgBW} /$ day
T2DM: Type 2 diabetes mellitus.

Figure 2 and Table 4 present further tests to determine differences between groups specifically as well as to find out which of these groups had the most significant HOMA-IR changes. For this test, it appears that the significance value between groups is if $p<0.05$. Based on the output in Table 4, it is known that the Sig value for K3 against K4 is 0.000 , K3 against $\mathrm{K} 5$ is $0.000, \mathrm{~K} 3$ against $\mathrm{K} 6$ is $0.000, \mathrm{~K} 3$ against $\mathrm{K} 7$ is $0.000, \mathrm{~K} 4$ for $\mathrm{K} 5$ is $1.000, \mathrm{~K} 4$ for $\mathrm{K} 6$ is $1.000, \mathrm{~K} 4$ for $\mathrm{K} 7$ is $1.000, \mathrm{~K} 5$ to $\mathrm{K} 6$ is $1.000, \mathrm{~K} 5$ to $\mathrm{K} 7$ is 0.322 , and $\mathrm{K} 6$ to $K 7$ is 1.000 . This shows that there is a significant difference in HOMA-IR on $\mathrm{K} 3$ against $\mathrm{K} 4, \mathrm{~K} 3$ against $\mathrm{K} 5$, $\mathrm{K} 3$ against $\mathrm{K} 6$, and $\mathrm{K} 3$ against $\mathrm{K} 7$. 


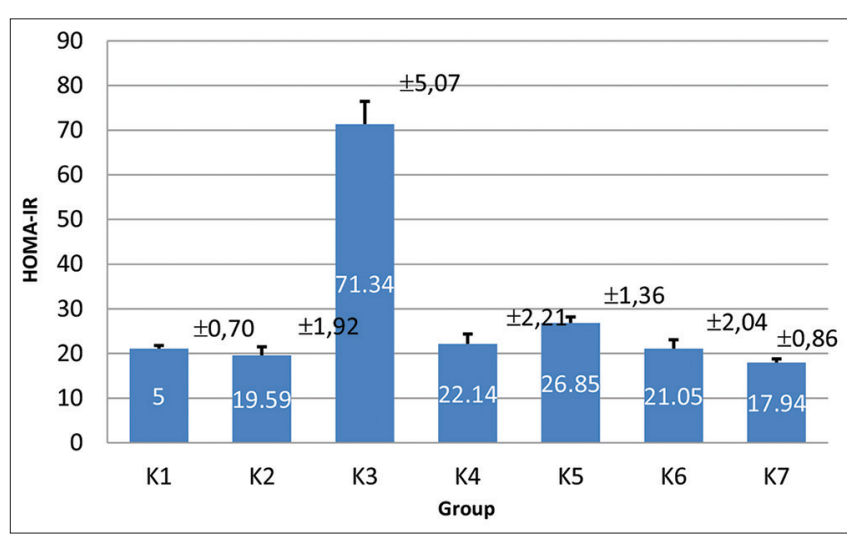

Figure 2: Diagram of mean and standard deviation of homeostatic model assessment - insulin resistance levels after intervention

\section{Discussion}

The experimental animals used in this study were 35 healthy male Wistar rats (Rattus norvegicus $\mathrm{sp}$.) who had met the inclusion and exclusion criteria. Wistar rats were divided into 2 highest groups, namely, the normal group that was not made the T2DM model $(n=10)$ and the T2DM model group $(n=25)$. All experimental animals in the T2DM model group were induced with a low dose of streptozotocin (STZ) $30 \mathrm{mg} / \mathrm{kg}$ (1 week interval) after being given an HFD for 5 weeks to make it a T2DM model. Wistar rats that had become T2DM were divided randomly into 5 groups, namely the T2DM group without treatment $(n=5)$, the T2DM group with metformin $(n=5)$, the T2DM group with the administration of Coffee Arabica Gayo Leaf Extract (C. arabica L.) at a dose of $150 \mathrm{mg} / \mathrm{kgBW} /$ day $(\mathrm{n}=5)$, the T2DM group was given the Coffee Arabica Gayo Leaf Extract (C. arabica L.) at a dose of $200 \mathrm{mg} / \mathrm{kgBW} /$ day $(n=5)$, and the T2DM group was given the Coffee Arabica Gayo Leaf Extract (C. arabica L.) at a dose of $250 \mathrm{mg} / \mathrm{kgBW} /$ day $(\mathrm{n}=5)$. Likewise, the group of mice that were not made the T2DM model was divided into two groups randomly, namely the normal control group without treatment $(n=5)$ and the normal control group with the administration of Coffee Arabica Gayo Leaf Extract (C. arabica L.) at a dose of $250 \mathrm{mg} / \mathrm{kgBW} /$ day $(n=5)$. Therefore, the total number of groups $(t)$ in this study was 7 groups consisting of 2 Normal groups and 5 T2DM groups. Of these 7 groups, there were 2 groups that did not receive treatment (K1 and $\mathrm{K} 3)$ and 5 groups that received treatment (K2, K4, K5, K6, K7).

Intervention of chlorogenic acid in Coffee Arabica Gayo Leaf in a long period of time was able to significantly decrease fasting BGLs, fasting insulin levels and therefore HOMA-IR levels. In the pathophysiology of T2DM, insulin resistance plays a big role in the mechanism. Insulin resistance itself can be caused by various factors, both modifiable and non-modifiable factors which then result in decreased glucose transport through decreased GLUT-4 translocation caused by decreased PI3K activity through signal transduction pathways and decreased AMPK activity through nonsignal transduction pathways. This decreases in translocation of GLUT-4 which then reduces the uptake of glucose in the blood resulting in an increase in BGLs. In this case, the untreated insulin resistance will cause T2DM. These components of PI3K, AMPK, and GLUT-4 in skeletal muscle are important in lowering the BGL and fasting insulin levels, therefore could improve insulin resistance [11].

In this study, it was found that the decrease in HOMA-IR values was greater in the T2DM model mice in the ethanol extract group of Coffee Arabica Gayo Leaf Extract (C. arabica L.) at a dose of $200 \mathrm{mg} / \mathrm{kgbb}$ and $250 \mathrm{mg} / \mathrm{kgbb}$ for 30 days compared to the metformin group and it was statistically significant with $p=0.002$. The results of this study are in line with the research of Roshan et al., who revealed that giving green coffee extract containing chlorogenic acid can significantly reduce the HOMA-IR index and consequently reduce insulin resistance. This was confirmed by several previous studies by giving chlorogenic acid content in green coffee for 14 weeks which resulted in an increase in insulin resistance in HFD-induced mice and a decrease in the value of HOMA-IR [4], [12].

In addition, the important role of insulin resistance leads to the need for an accurate examination of insulin resistance levels as well. HOMA is a method for assessing $\beta$ cell function and insulin resistance from basal (fasting) glucose and insulin concentrations. Therefore, this study expects an improvement in insulin resistance signal transduction at the molecular level by giving Coffee Arabica Gayo Leaf Extract (C. arabica L.) to T2DM model mice so that the state of insulin resistance can be improved [13].

\section{Conclusion}

In this study, it was found the Coffee Arabica Gayo Leaf Extract (C. arabica L.) can significantly decrease HOMA-IR levels $(p=0.002)$ at a dose of $200 \mathrm{mg} / \mathrm{kgBW} /$ day and $250 \mathrm{mg} / \mathrm{kgBW}$. The decrease of HOMA-IR levels is greater than The T2DM group that received metformin and the T2DM group without treatment. It also shows that there is a significant difference in HOMA-IR on different groups such as $\mathrm{K} 3$ against $\mathrm{K} 4, \mathrm{~K} 3$ against $\mathrm{K} 5, \mathrm{~K} 3$ against $\mathrm{K} 6$, and $\mathrm{K} 3$ against $\mathrm{K} 7$ in Post Hoc Bonferroni Test.

\section{Acknowledgment}

The authors gratefully acknowledge that this study is supported the Universitas Sumatera Utara, the 
Ministry of Research and Technology, and the higher Education Republic of Indonesia. Support is from the research grant DRPM 2020, contract number 11/AMD/ E1/KP.PTNBH/2020, tanggal 11 Mei 2020. We would also like to thank all who contributed to this research.

\section{References}

1. International Diabetes Federation. IDF Diabetes Atlas. $7^{\text {th }}$ ed. Brussels, Belgium: International Diabetes Federation; 2019.

2. Usha $\mathrm{P}$, Puneeth $\mathrm{N}$, Udayakiran $\mathrm{N}$. Awareness of Type 2 diabetes mellitus in rural population of Mangalore, South India. Int J Med Sci Public Health. 2018;7(6):462-3. https://doi. org/10.5455/ijmsph.2018.0307013032018

3. Vergotine Z. Molecular Investigation of Genetic Factors Associated with Insulin Resistance and Obesity in a South African Population. South Africa: Stellenbosch University; 2015.

4. Rodrigo M, Carillo-Larco, Jaime M, Robert H. The HOMA-IR performance to identify new diabetes cases by degree of urbanization and altitude in Peru: The CRONICAS cohort study. J Diabetes Res. 2018;2018:7434918. https://doi. org/10.1155/2018/7434918

PMid:30648116

5. Chen XM, Ma Z, Kitts DD. Effects of processing method and age of leaves on phytochemical profiles and bioactivity of coffee leaves. Food Chem. 2018;249:143-53. https://doi.org/10.1016/j. foodchem.2017.12.073

PMid:29407917

6. Ahren B. Avoiding hypoglycemia: A key to success for glucoselowering therapy in Type 2 diabetes. Vasc Health Risk Manag. 2013;9:155-63. https://doi.org/10.2147/vhrm.s33934

\section{PMid:23637538}

7. Tajik N, Tajik M, Mack I, Enck P. The potential effects of chlorogenic acid, the main phenolic components in coffee, on health: A comprehensive review of the literature. Eur J Nutr. 2017;56(7):2215-44. https://doi.org/10.1007/ s00394-017-1379-1

\section{PMid:28391515}

8. Marques V, Farah A. Chlorogenic acids and related compounds in medicinal plants and infusions. Food Chem. 2018;113(4):13706. https://doi.org/10.1016/j.foodchem.2008.08.086

9. Federer WT. Experimental Design: Theory and Application. Pada; 2010. Hanafiah KA. Rancangan percobaan-teori dan aplikasi. Vol. 3. Jakarta: Raja Grafindo Persada; 1995. p. 9-10.

10. Gayoso-Diz P, Otero-González A, Rodriguez-Alvarez MX, Gude F, García F, De Francisco A, et al. Insulin resistance (HOMAIR) cut-off values and the metabolic syndrome in a general adult population: Effect of gender and age: EPIRCE crosssectional study. BMC Endocr Disord. 2013;13:47. https://doi. org/10.1186/1472-6823-13-47

PMid:24131857

11. Vinayagam, $R, X u$ B. Antidiabetic properties of dietary flavonoids: A cellular mechanism review. Nutr Metab (Lond). 2015;12:60. https://doi.org/10.1186/s12986-015-0057-7

PMid:26705405

12. Roshan H, Nikpayam O, Sedaghat M, Sohrab G. Effects of green coffee extract supplementation on anthropometric indices, glycaemic control, blood pressure, lipid profile, insulin resistance and appetite in patients with the metabolic syndrome: A randomised clinical trial. Br J Nutr. 2018;119(03):250-8. https:// doi.org/10.1017/s0007114517003439

PMid:29307310

13. Gutch M, Kumar S, Razi SM, Gupta KK, Gupta A. Assessment of insulin sensitivity/resistance. Indian J Endocrinol Metab. 2015;19(1):160-4. https://doi.org/10.4103/2230-8210.146874 PMid:25593845 